\title{
Comparative Study on Ondansetron with Granisetron in the Prevention of Postoperative Nausea and Vomiting in Subjects Undergoing Laparoscopic Cholecystectomy Under General Anesthesia
}

\section{Pervez Taneja1, Yogesh Bansal ${ }^{2 *}$ and Anil Ohri ${ }^{1}$}

${ }^{1}$ Anesthesia Department, Pandit Jawahalal Nehru Government Medical College and Hospital, Chamba, HP, India

${ }^{2}$ Biochemistry Department, Pandit Jawahalal Nehru Government Medical College and Hospital, Chamba, HP, India

*Corresponding Author: Yogesh Bansal, Associate Professor, Biochemistry

Department, Pandit Jawahalal Nehru Government Medical College and Hospital, Chamba, HP, India.
Received: January 22, 2021

Published: February 25, 2021

(c) All rights are reserved by Yogesh Bansal., et al.

\begin{abstract}
Laparoscopic cholecystectomy leads to post-operative nausea and vomiting. This is cured by using antagonist of 5 HT- 3 receptors present on enterochromaffin cells or vagus nerves terminals. It is of interest to compare the efficacy of ondansetron and granisetron in patients undergoing laparoscopic cholecystectomy. 40 patients of age between 18-58 years were selected, and divided into two groups where group A ( $\mathrm{n}=20)$ includes the patients administered with ondansetron $(4 \mathrm{mg})$ and group B (n=20) includes the patients administered with granisetron ( $3 \mathrm{mg}$ ). Patients were observed at a time interval of $0 \mathrm{~h}, 1 \mathrm{~h}, 2 \mathrm{~h}, 6 \mathrm{~h}, 12 \mathrm{~h}$ and $24 \mathrm{~h}$ postoperatively and the incidence of nausea, retching or vomiting and post operative nausea and vomiting (PONV) was measured using the visual analogue score (VAS). $10-30 \%(P=0.05)$ of total post-operative patients were found with PONV in an initial $2 \mathrm{~h}$. As per VAS, $20-30 \%$ $(P=0.05)$ and $10-15 \%(P=0.05)$ of post-operative patients in group $A$ and $B$ has an incidence of nausea, vomiting and PONV in initial 2h. respectively. After 24 hours, 60\% ( $P=0.05)$ of patients in group A and 70\% $(P=0.05)$ in group B were free from emesis. Thus, the incidence of vomiting (20\%) as compared to nausea (15\%) and PONV (20\%) are less in subjects who have received granisetron. Data showed that granisetron is a better antinausea drug.
\end{abstract}

Keywords: Ondansetron; Granisetron; Laparoscopic Cholecystectomy; PONV

\section{Background}

Distressing symptoms like postoperative nausea and vomiting (PONV) commonly occur after laparoscopic surgeries under general anesthesia [1]. PONV is said to have a multifactorial etiology [2] and researchers observed that reduced morbidity is associated with cholecystectomy by laparoscopic surgery [2] (an accepted procedure for symptomatic cholelithiasis), but this procedure has increased the incidence of PONV (53-72\%) [3,4]. Carbon dioxide insufflation led to the dilatation of intentional loops and observed as a risk factor for nausea and vomiting after laparoscopic surgery. After the stimulation of gut wall-associated mechanoreceptors, se- rotonin is synthesized, which triggers the medulla's chemoreceptors, and finally, vagus nerve terminals are activated and evoke an emetic response $[5,6]$.

Granisetron is first-generation, non-competitive, 5 HT-3 antagonists $[7,8]$. It is used as an anti-emetic drug [9]. It acts directly on enterochromaffin cells and acts solely through 5 HT-3 receptors on vagal afferents [9]. It crosses the placental membrane in a dose-dependent manner [10]. It is administered with various routes. It has similar efficacy compared to other first-generation 5HT-3 antagonists (tropisetron, ondansetron, and dolasetron) [11]. 
Ondansetron is also a first selective $5 \mathrm{HT}$ antagonist and safest effective anti-emetic agents. It has a similar mechanism of action with granisetron $[12,13]$. It affects the vagus nerve terminals where 5-HT-3 are present. It is well known that the vagus nerve is responsible for the triggering of nausea and vomiting, and this drug is metabolised with the help of cytochrome $\mathrm{P}_{450}$ present in the liver $[14,15]$.

It is suggested that the selection of both drugs over the other be based on comparison bases for the prevention of postoperative nausea and vomiting in patients undergoing laparoscopic cholecystectomy under general anesthesia.

Therefore, we conducted a study to compare the efficacy of the 5 HT-3 antagonists i.e., granisetron against ondansetron, that has proven to be an effective and safest drug in preventing nausea and vomiting after laparoscopic cholecystectomy. This study aims to compare ondansetron with granisetron in preventing postoperative nausea and vomiting in patients undergoing laparoscopic cholecystectomy under general anesthesia.

\section{Material and Methods}

This randomised, cross sectional study was conducted at Pandit Jawaharlal Nehru Govt Medical College and Hospital Chamba HP, India. The said work was approved from the ethical committee of the same medical college. Each subject has given written consent and informed as per regulation of randomized, double-blind study. This study was conducted in a prospective, cross sectional and randomized fashion from July 2018 to Oct. 2018. Preoperative baseline values of heart rate and blood pressure and mandatory biochemical tests were recorded.

Forty subjects between 18-58 years were selected with ASA grade I-II (American society of Anesthesiologists) undergoing elective laparoscopic cholecystectomy under general anaesthesia [14]. We excluded subjects with any of the following symptoms like allergy to any drug, vomiting/retching/nausea/anti-emetic in $24 \mathrm{~h}$ preceding administration of anesthesia. Subjects on chronic steroids, prokinetics, anti-emetic/ antacids, menstruating/ lactating or pregnant females, history of alcohol or substance abuse, subjects with chronic diseases, QT prolongation on preoperative electrocardiography.

As per the regulations of the computer based randomization technique, these subjects were equally divided into group $\mathrm{A}$ ( $\mathrm{n}=$ 20 ) with ondansetron $4.0 \mathrm{mg}$ (fixed-dose), group B $(\mathrm{n}=20)$ with granisetron $0.75 \mathrm{mg}$ (fixed dose). Care was taken on the prepara- tion of study drugs with the use of identical syringes [16]. All practitioners who are working for this research work were blinded to the allocation of groups.

For randomized control study 40 patients of age between 18-58 years were selected and divided into two groups where group A ( $\mathrm{n}$ $=20$ ) includes the patients administered with ondansetron (4mg) and group B $(n=20)$ includes the patients administered with granisetron $(0.75 \mathrm{mg})$. Patients were observed at a time interval of $0 \mathrm{~h}, 1 \mathrm{~h}, 2 \mathrm{~h}, 6 \mathrm{~h}, 12 \mathrm{~h}$ and $24 \mathrm{~h}$ postoperatively and the incidence of nausea, retching or vomiting and PONV was measured using visual analogue score (VAS).

\section{Anesthetics procedure}

The patients were kept fasting after 10 PM a day before the surgery, and the baseline parameters were taken and recorded. Patients were anesthetised as per regulations under randomised control study. On arrival in operation theater, routine monitoring ECG, $\mathrm{pCO}_{2}$ and baseline BP were recorded with the pulse oximeter.

The selected drugs were diluted with $10 \mathrm{ml}$ of saline. The drug was given in period of $10 \mathrm{~min}$ as per the randomised schedule. The patient was induced after preoxygenation for 3 min with inj. Propofol with $10 \mathrm{mg}$ per Kg body weight and intubation with an appropriate size tube with injection Vecuronium bromide 0.1 mg per Kg body weight and anaesthesia were maintained with $\mathrm{O}_{2}: \mathrm{N}_{2} \mathrm{O}(50 \%: 50 \%)$, Isoflurane (0.8-1.0\%).

Muscle relaxation was maintained with boluses of injection Vecuronium bromide, and intermittent positive pressure with endtidal $\mathrm{CO}_{2}$ between $30-35 \mathrm{~mm} \mathrm{Hg}$ was maintained. A ryles tube was placed for emptying airs and secretions from the stomach. An IV line was maintained with ringer lactate solution $2.0 \mathrm{ml}$ per $\mathrm{Kg}$ body weight. During the surgery, a strict watch was maintained in monitoring the intra-abdominal pressure (IAP) between 10-12 mm of Hg. At the end of the surgery, Ryle's tube was removed after doing suction. Injection glycopyrrolate and neostigmine were given as reversal to remove the residual neuromuscular block, and extubation was done after adequate neuromuscular reversal. Injection diclofenac sodium $1 \mathrm{mg} / \mathrm{kg}$ body weight was administered IV half an hour before the end of the surgery.

An IV line was maintained, and intravenous crystalloids were given $2 \mathrm{ml} / \mathrm{kg}$ body after the surgery, and the patient was kept postanaesthesia care unit, and monitoring was continuously done. 
Comparative Study on Ondansetron with Granisetron in the Prevention of Postoperative Nausea and Vomiting in Subjects Undergoing Laparoscopic Cholecystectomy Under General Anesthesia

\section{Measurements [17]}

Visual Analogue Score (VAS) was used to measure the pain intensity among the group ${ }^{17}$. Scale was divided into four points i.e. $(0$, none; 1 , nausea; 2 , retching; 3 , vomiting). If VAS score will come greater than four after that rescue analgesia was provided with injection paracetamol (1gm/ $\mathrm{kg}$ of body weight) intravenously. Importantly, headache, diarrhea, and dizziness was recorded to confirm the adverse effect of selected drugs.

\section{Statistical analysis}

Collected data were assessed using statistical package for the social sciences ver. $23.0^{\circledR}$ software where $\mathrm{p}<0.05$ was considered statistically significant. Results were expressed in mean \pm standard deviation of the values, and chi-square test was performed among the groups to find out the efficacies between selected drugs.

\section{Results}

$10-30 \%(\mathrm{P}=0.05)$ of total post-operative patients were found with PONV in an initial $2 \mathrm{~h}$. As per VAS, $20-30 \%(\mathrm{P}=0.05)$ and 10$15 \%(\mathrm{P}=0.05)$ of post-operative patients in group $\mathrm{A}$ and $\mathrm{B}$ has an incidence of nausea, vomiting and PONV in initial $2 \mathrm{~h}$. respectively. After 24 hours, $60 \%(\mathrm{P}=0.05)$ of patients in group $\mathrm{A}$ and $70 \%(\mathrm{P}=$ 0.05 ) in group B were free from emesis.

The present study has been planned and performed to compare two drugs (ondansetron and granisetron) in the prevention of postoperative nausea and vomiting in patients undergoing laparoscopic cholecystectomy under general anaesthesia. In the present study, $4.0 \mathrm{mg}$ and $0.75 \mathrm{mg}$ of body weight of ondansetron and granisetron were used, respectively.

Table 1 presents the characterization of the study population by age, sex, BMI, ASA, during of operation and duration of anaesthesia (min.). In addition to this, the total lipid profile and renal function test levels were assessed before and after $24 \mathrm{~h}$ of surgery (Table 1 ).

Table 2 presents the incidence of nausea, vomiting and PONV among the patients among the group A and group B. Statistically decrease in the incidence of PONV was observed in both groups A and B. A statistically significant decrease was found in the incidence of nausea vomiting PONV in group B in comparison group A. In this comparative study, the incidence of nausea, vomiting and PONV was significantly decreased in patients having fixed dose of granisetron.

The levels of total lipid LDL and TG were found significantly decreased after $24 \mathrm{~h}$ of surgery $(\mathrm{p}<0.05)$ but it was found that

\begin{tabular}{|c|c|c|c|}
\hline \multicolumn{3}{|c|}{ Total number of patients understudy $=\mathbf{4 0}$} & \multirow[t]{2}{*}{$\mathbf{P}$} \\
\hline $\begin{array}{l}\text { Drugs under } \\
\text { study }\end{array}$ & $\begin{array}{c}\text { Ondansetron } \\
(n=20) \\
(4.0 \mathrm{mg} \text { fixed } \\
\text { dose })\end{array}$ & $\begin{array}{c}\text { Granisetron } \\
(n=20) \\
(0.75 \mathrm{mg} \\
\text { fixed dose) }\end{array}$ & \\
\hline Age (years) & $48 \pm 11$ & $45 \pm 14$ & 0.231 \\
\hline $\begin{array}{l}\text { Sex ( Male/ } \\
\text { Female) }\end{array}$ & $06 / 14$ & $05 / 15$ & \\
\hline Weight (kg) & $65.23 \pm 12.88$ & $69.42 \pm 15.64$ & 0.273 \\
\hline Height (M) & $5.71 \pm 0.49$ & $5.88 \pm 0.68$ & 0.431 \\
\hline BMI $\left(\mathrm{kg} / \mathrm{M}^{2}\right)$ & $23.78 \pm 3.21$ & $24.22 \pm 4.03$ & 0.122 \\
\hline ASA Class I:II & $18: 12$ & $21: 09$ & \\
\hline Smoking habit & 05 & 04 & \\
\hline $\begin{array}{l}\text { Motion sick- } \\
\text { ness (History) }\end{array}$ & 06 & 08 & \\
\hline $\begin{array}{l}\text { Total lipid ( } \\
\text { mg/dL) } \\
\text { Before } \\
\text { surgery/after } \\
\text { surgery }\end{array}$ & $\begin{array}{c}225.05 \pm \\
41.55 / 197.89 \pm \\
34.74\end{array}$ & $\begin{array}{c}220 \pm \\
35.41 / 180 \pm \\
30.55\end{array}$ & 0.144 \\
\hline $\begin{array}{l}\text { LDL( mg/dL) } \\
\text { Before } \\
\text { surgery/after } \\
\text { surgery }\end{array}$ & $\begin{array}{c}114.51 \pm \\
25.65 / 97.15 \pm \\
24.88\end{array}$ & $\begin{array}{c}110 \pm \\
22.48 / 80 \pm \\
21.36\end{array}$ & 0.156 \\
\hline $\begin{array}{l}\text { TG( mg/dL) } \\
\text { Before } \\
\text { surgery/ after } \\
\text { surgery }\end{array}$ & $\begin{array}{c}168.45 \pm \\
29.85 / 145.84 \pm \\
22.47\end{array}$ & $\begin{array}{c}162 \pm \\
27.59 / 154 \pm \\
21.84\end{array}$ & 0.148 \\
\hline $\begin{array}{l}\text { Urea }(\mathrm{mg} / \mathrm{dL}) \\
\text { Before } \\
\text { surgery/after } \\
\text { surgery }\end{array}$ & $\begin{array}{c}28.75 \pm \\
9.46 / 32.14 \pm \\
11.65\end{array}$ & $\begin{array}{c}25.54 \pm \\
8.99 / 31.25 \pm \\
11.84\end{array}$ & 0.169 \\
\hline $\begin{array}{l}\text { Creatnine( } \mathrm{mg} / \\
\mathrm{dL} \text { ) } \\
\text { Before } \\
\text { surgery/after } \\
\text { surgery }\end{array}$ & $\begin{array}{c}0.98 \pm \\
0.25 / 1.11 \pm \\
0.41\end{array}$ & $\begin{array}{c}0.84 \pm \\
0.21 / 1.09 \pm \\
0.41\end{array}$ & 0.178 \\
\hline $\begin{array}{l}\text { During of } \\
\text { Operation } \\
\text { (Min.) }\end{array}$ & $55.06 \pm 16.43$ & $59.17 \pm 17.28$ & 0.688 \\
\hline $\begin{array}{l}\text { Duration of } \\
\text { Anesthesia } \\
\text { (Min) }\end{array}$ & $77.12 \pm 14.53$ & $79.42 \pm 26.34$ & 0.734 \\
\hline PNOV (History) & One & No & \\
\hline $\begin{array}{l}\text { PNOV } \\
\text { (Incidence) }\end{array}$ & 12 & 08 & \\
\hline
\end{tabular}

Table 1: Demographic profile of patients understudy. Note: BMI- Body mass index, SD- Standard Deviation, ASA -American society of Anesthesia, Values are mean \pm SD or Number of patients (Percentage). 


\begin{tabular}{|l|c|c|c|c|c|c|}
\hline Drugs & \multicolumn{2}{|c|}{ Group A (n=20) } & \multicolumn{3}{c|}{ Group B (n=20) } \\
\hline & $\begin{array}{c}\text { Nausea } \\
\left(\%^{\text {age }}\right)\end{array}$ & $\begin{array}{c}\text { Vomiting } \\
\left(\%^{\text {age }}\right)\end{array}$ & $\begin{array}{c}\text { PONV } \\
\left(\% \%^{\text {age }}\right)\end{array}$ & $\begin{array}{c}\text { Nausea } \\
\left(\%^{\text {age }}\right)\end{array}$ & $\begin{array}{c}\text { Vomiting } \\
\left(\%^{\text {age }}\right)\end{array}$ & $\begin{array}{c}\text { PONV } \\
\left(\%{ }^{\text {age }}\right)\end{array}$ \\
\hline $0 \mathrm{~h}$ & 00 & 00 & $01(05.0)$ & 00 & 00 & 00 \\
\hline $01 \mathrm{~h}$ & $05(25.0)$ & $05(25.0)$ & $04(20.0)$ & $02(10.0)$ & $02(10.0)$ & $03(15.0)$ \\
\hline $02 \mathrm{~h}$ & $06(30.0)$ & $05(25.0)$ & $06(30.0)$ & $03(15.0)$ & $03(15.0)$ & $02(10.0)$ \\
\hline $06 \mathrm{~h}$ & $07(35.0)$ & $06(30.0)$ & $07(35.0)$ & $05(25.0)$ & $05(25.0)$ & $06(30.0)$ \\
\hline $12 \mathrm{~h}$ & $9(45.0)$ & $09(45.0)$ & $08(40.0)$ & $06(30.0)$ & $06(30.0)$ & $05(25.0)$ \\
\hline $24 \mathrm{~h}$ & $10(50.0)$ & $09(45.0)$ & $10(50.0)$ & $06(30.0)$ & $06(30.0)$ & $06(30.0)$ \\
\hline
\end{tabular}

Table 2: Incidence of nausea, vomiting and PONV among the groups.

Note: Values are expressed as number of patients, $\mathrm{p}<0.05$ compared with control. levels of urea and creatinine were significantly increased. Group B showed a statistically significant lower incidence of nausea vomiting and PONV as compare to ondansetron ( $p<0.05)$.

\section{Discussion and Conclusion}

The present study was planned to compare to the antiemetic effect of ondansetron and granisetron, and the results of the present study showed a significant decrease in the incidence of nausea vomiting and PONV in group A and B after laparoscopic cholecystectomy under general anaesthesia. However, it was observed in our study that incidence of PONV was even much lower in the patients receiving granisetron, i.e., in group $\mathrm{B}$.

Granisetron decreases antiemetic symptoms in a dose-dependent manner i.e. 20, 40 and 80 microgram $/ \mathrm{kg}$ of body weight of

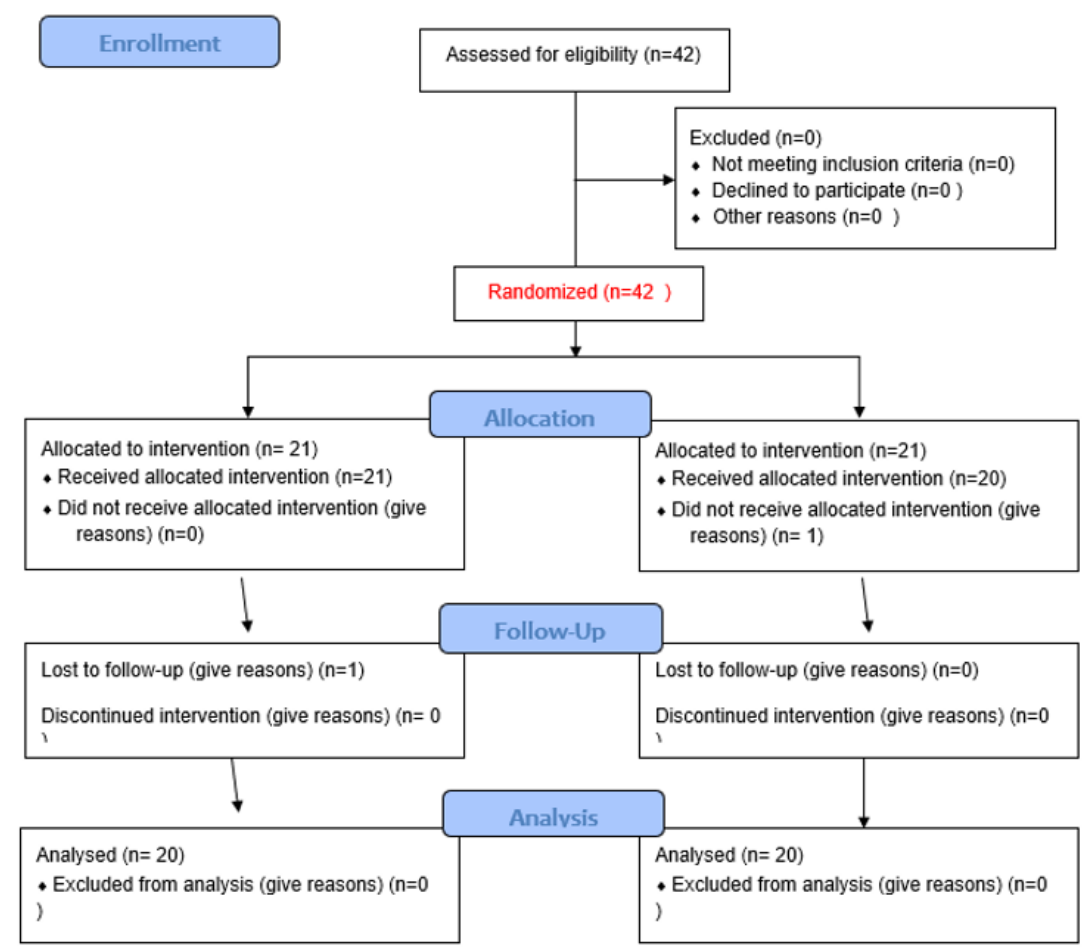

Figure 1

granisetron and also reduces PONV [7]. Researchers reported that ondansetron ( $4 \mathrm{mg}$ ) has significantly higher antiemetic symptoms as compare to granisetron $[5,6]$. They also reported that the anti- emetic symptoms with ondansetron administrated group last for 4-5 h, and these findings were similar to other researcher $[6,18]$. 
PONV was found to be 25\% with ondansetron and 20\% with granisetron where granisetron $1 \mathrm{mg}$ and ondansetron $4 \mathrm{mg}$ used for modified radical mastectomy which confirms that granisetron is more effective in reducing the incidence of PONV [19]. Similarly, In our study, the overall incidence of PONV was found to be $40 \%$ in group $\mathrm{A}$ and $30 \%$ in group $\mathrm{B}$ due to difference in $\mathrm{t} 1 / 2$.

Ondansetron, granisetron, and dexamethasone have decreased PONV in patients undergoing laparoscopic cholecystectomy [9], and the total incidence of PONV was reduced to $35 \%$ with ondansetron, $30 \%$ with granisetron, and $25 \%$ with dexamethasone respectively as compare to $75 \%$ with placebo(p $<0.05)[6,9]$ and this study supports the finding observed in your study.

In our results, the incidence of nausea vomiting was significantly decreased in patients having fixed dose of granisetron was further supported by other research workers who worked on prevention of PONV with dose variation of granisetron and authors also reported that there was statistically decrease in the incidence of PONV was observed in both ondansetron and granisetron in comparison to control group [20]. These results were found similar to a study with ondansetron (100microgram $/ \mathrm{kg}$ ) and granisetron (40 micrograms $/ \mathrm{kg}$ ) administered intravenously and observed that granisetron significantly decreases the PONV in patients after 6hours of strabismus surgery [21].

We also noted that incidence of vomiting (20\%) as compared to nausea $(15 \%)$ is significantly less in subjects with granisetron ( $p>0.05$ ) that shows better antiemetic effect than the anti-nausea effect of ondansetron. Also, granisetron shows better anti-nausea (8\%) effect than antiemetic effect.

\section{Acknowledgement}

The authors gratefully acknowledge the Department of Anaesthesia and Biochemistry Pandit Jawaharlal Nehru Govt Medical College and Hospital Chamba HP, India for providing laboratory space and operation theatre and other facilities for conducting the research activity. All the authors are equally participated.

\section{Bibliography}

1. Kannan S., et al. "Drugs for preventing post-operative nausea and vomiting in patients undergoing laparoscopic cholecystectomy: Network Meta-Analysis of Randomized Clinical Trials and Trial Sequential analysis". International Journal of Surgery 69 (2019): 1-12.
2. Shirin S., et al. "comparison of ondansetron and granisetron effects for prevention of nausea and vomiting following strabismus". Open Access Macedonian Journal of Medical Sciences 7.19 (2019): 3195-3200.

3. Milnes V., et al. "Aprepitant: A new modality for the prevention of postoperative nausea and vomiting: An evidence-based review". Journal of PeriAnesthesia Nursing 30.5 (2015): 406-417.

4. Wu SJ., et al. "Comparison of the efficacy of ondansetron and granisetron to prevent postoperative nausea and vomiting after laparoscopic cholecystectomy: A systematic review and meta-Analysis". Surgical Laparoscopy Endoscopy and Percutaneous Techniques 23.1 (2013): 79-87.

5. Fujii Y. "Management of postoperative nausea and vomiting in patients undergoing laparoscopic cholecystectomy". Surgical Endoscopy 25.3 (2011): 691-695.

6. Savant K., et al. "Comparison of ondansetron and granisetron for antiemetic prophylaxis in maxillofacial surgery patients receiving general anesthesia: A prospective, randomised, and double-blind study". Journal of the Korean Association of Oral and Maxillofacial Surgeons 42 (2016): 84-89.

7. Fujii Y., et al. "Effects of granisetron in the treatment of nausea and vomiting after laparoscopic cholecystectomy: a dose-ranging study". Clinical Therapy 26.7 (2004): 1055-1060.

8. Loewen PS., et al. "5-HT3 receptor antagonists vs traditional agents for the prophylaxis of postoperative nausea and vomiting". Canadian Journal of Anesthesia 47.10 (2000): 1008-1018.

9. Wilson AJ., et al. "Single-dose i.v. granisetron in the prevention of postoperative nausea and vomiting". British Journal of Anesthesia 76 (1996): 515-518.

10. Edwin NA and Todd LH. "Pharmacogenetics of postoperative nausea and vomiting". Journal of PeriAnesthesia Nursing 34.6 (2019): 1088-1105.

11. Candiotti KA., et al. "A randomized, double-blind study to evaluate the efficacy and safety of three different doses of palonosetron versus placebo for preventing postoperative nausea and vomiting. Palonosetron 04-06 Study Group". Anesthesia and Analgesia 107.2 (2008): 445-451.

12. Anh LN., et al. "Extended Release Granisetron: Review of pharmacologic considerations and clinical role in the perioperative Setting". Saudi Journal of Anesthesia 13.3 (2019): 231-236. 
13. Ahmet A., et al. "Comparison of ondansetron, tropisetron, and palonosetron for the prevention of postoperative nausea and vomiting after middle ear surgery". Current Therapeutic Research, Clinical and Experimental 91 (2019): 17-21.

14. Patel P., et al. "Safety of clinical practice guideline-recommended antiemetic agents for the prevention of acute chemotherapy-induced nausea and vomiting in pediatric patients: a systematic review and meta-analysis". Expert Opinion on Drug Safety 18.2 (2019): 97-110.

15. Guilherme OC., et al. "Palonosetron versus ondansetron for prevention of nausea and vomiting after total abdominal hysterectomy under spinal anesthesia with intrathecal morphine: A double-blind, randomized controlled trial". BMC Anesthesiology 19 (2019): 159.

16. Sabin G., et al. "Ondansetron and granisetron for prevention of postoperative nausea and vomiting following laparoscopic cholecystectomy". Journal of Nepal Medical Association 52.193 (2014): 682-686.

17. Leksowski K., et al. “Ondansetron, metoclopramid, dexamethason, and their combinations compared for the prevention of postoperative nausea and vomiting in patients undergoing laparoscopic cholecystectomy: A prospective randomized study". Surgical Endoscopy 20.6 (2006): 878-882.

18. Salome JI., et al. "Comparing the efficacy of aprepitant and ondansetron for the prevention of postoperative nausea and vomiting (PONV): A double blinded, randomised control trial in patients undergoing breast and thyroid surgerie". Indian Journal of Anesthesia 63.4 (2019): 289-294.

19. Dua N., et al. "Granisetron and ondansetron for prevention of nausea and vomiting in patients undergoing modified radical mastectomy". Anesthesia Intensive Care 32 (2004): 761-764.

20. Erhan Y., et al. "Ondansetron, granisetron, and dexamethasone, compared for the prevention of postoperative nausea and vomiting in patients undergoing laparoscopic cholecystectomy : A randomized placebo-controlled study". Surgical Endoscopy 22.6 (2008): 1487-1492.

21. Mohammadi S., et al. "Efficacy of granisetron on prevention of shivering, nausea and vomiting during cesarean delivery under spinal anesthesia: A randomized double-blinded clinical trial". Journal of Obstetric Anesthesia 5 (2015): 22-26.

\section{Assets from publication with us}

- Prompt Acknowledgement after receiving the article

- Thorough Double blinded peer review

- Rapid Publication

- Issue of Publication Certificate

- High visibility of your Published work

Website: www.actascientific.com/

Submit Article: www.actascientific.com/submission.php Email us: editor@actascientific.com

Contact us: +919182824667

Citation: Yogesh Bansal., et al. "Comparative Study on Ondansetron with Granisetron in the Prevention of Postoperative Nausea and Vomiting in Subjects Undergoing Laparoscopic Cholecystectomy Under General Anesthesia". Acta Scientific Pharmaceutical Sciences 5.3 (2021): 44-49. 